\title{
GOOGLE CLASSROOM-BASED LEARNING: LOOKING DEEPER INTO THE SENIOR VOCATIONAL SCHOOL EFL LEARNING IN THE PANDEMIC CONTEXT
}

\author{
N.P. Santi ${ }^{1}$, D.K. Tantra ${ }^{2}$, M.H. Santosa ${ }^{3}$ \\ ${ }^{123}$ English Language Education, Universitas Pendidikan Ganesha, Singaraja \\ e-mail: putusanti078@gmail.com, komang.tantra@undiksha.ac.id, mhssantosa@undiksha.ac.id
}

\begin{abstract}
The present research measured the teachers' ability and identified the constraints in preparing and implementing lesson plans as well as the students' constraints in learning English for Occupational Purposes (EOP) through Google Classroom during the pandemic Covid-19 in the Senior Vocational High School Denpasar. The design implemented was mixed method quantitatively and qualitatively. Data were collected by means of five instruments, namely teachers' ability and constraints in preparing and implementing lesson plan, and students' constrain in EOP through Google classroom. The research findings show that the teachers were less able in preparing and implementing lesson plans for EOP through Google Classroom. The constrain in EFL students of EOP through Google Classroom learning paradigm. The conclusion the teachers should improve their ability in developing learning indicators using operational and measurable words. It is suggested to understand of taxonomy bloom and both teachers and students should improve their motivation in online learning.
\end{abstract}

\section{Keywords: EOP; Google Classroom; Implementation; Preparation}

\section{INTRODUCTION}

Varieties of on-line learning platforms in EFL have been implemented with varying degrees of success world-widely. For examples, Google Classroom, Google meet, Video Call Classroom, Schoology, Instagram to mention afew (Namaziandostet al, 2020).Fonseca and Peralta (2019) studied the use of Google Classroom as an educational platform in the course of composition at Universidad National. They concluded that Google Classroom brought about benefits that allow students and teachers in implementing EOP with ease. They also found that the students practiced EOP for both academic and non-academic purposes.

In another work, Dashtestani (2013) explored the attitude of Iranian teacher toward English as foreign language which was implemented by mobile assisted language learning (MALL). The target participant was 168 teachers. Interview was conducted to 55 teachers. As the result, the study showed positive attitude toward Mobile Assisted Language Learning. The teachers argued that, Internet could give wide benefit for language learning and facilitated language teaching and learning process. It would improve communication, interaction, and problem-solving, but the teachers argued that they did not have skill in developing MALL in the classroom. The result of the study may be related to the concept of digital native. Santosa (2017) stated that today's students were different for those who were born before 1990s. The students who were born before 1990s may have different learning style and needs to the students who were born 1990s-2000s.

The present research was focused on teachers' ability and constraints in preparing and implementing English for Occupational Purposes' (EOP) lesson plans as well as students' constraints in EFL through Google Classroom platform in the Senior Vocational High School in Denpasar. Before the Covid-19 pandemic, lesson plans were organized by the so-called Musyawarah Guru Mata Pelajaran (MGMP) Bahasa Inggrisor EFL Teachers' Coordinating Group. EFL teachers used and implemented EFL learning processes using such compromised lesson plans in a face-to-face or unilateral interaction in the Senior Vocational High School Denpasar. After outbreak of the Covid-19 pandemic, the Ministry of National Education and Culture alternated EFL learning processes to on-line learning platform. 
The policy on on-line learning platform brings about new challenges and difficulties to both students and teachers, especially in Senior Vocational High School in Denpasar. Generally, EFL teachers might confront difficulty in preparing and implementing lesson plans through Google Classroom. Preparing and implementing lesson plans through Google Classroom require not only the teachers' ability, but also their expertise to characterize EOP as an easy-to-learn, integrating with lots of applications and websites, moving freely from one thing to another easily, and making use optimally G Suit documents.

Specific difficulties might confront EFL teachers in preparing lesson plans through Google Classroom in Senior Vocational High School in Denpasar were related to ability in 1) relating learning indicators with basic competency, 2) relating learning materials, learning indicators with basic competency, 3) relating learning methods or techniques with learning materials, learning indicators with basic competency, 4) relating learning procedures or steps in EOP, 5) relating evaluation and learning indicators, 6) relating evaluation instruments and techniques with learning indicators, 7) relating Information Technology to EOP, and 8) using Information Technology, especially Google Classroom platform in EOP. Another difficulties might confront EFL teachers in implementing lesson plans through Google Classroom platform, especially teachers' ability in, 1) opening EOP class, 2) mastering learning materials, 3) implementing scientific approach, 4) selecting appropriate learning media for EOP, 5) utilizing the already selected learning media in EOP, 6) managing classroom for EOP, 7) using oral as well as written English in EOP, 8) showing appropriate gestures in EOP, and 9) implementing good technique in EOP through Google Classroom platform.

On-line EFL through Google Classroom might confront students in Senior Vocational High School in Denpasar. They might be confronted with facilitative and technical problems in 1) possessing a desktop/laptop/mobile phone, 2) logging to Google Classroom without difficulty or without others' assistance, 3) using account to log in, 4) selecting account to log in, 5) log in without difficulty, 6) joining the classroom, 7) switching between accounts, 8) connecting without troubles, 9) posting comments through Google Classroom,10) cancelling comments after posting through Google Classroom, 11) finding problems with e-mail, either in sending or receiving e-mail, 12) turning in assignments through Google Classroom, 13) getting enclosures or handouts from teachers, 14) using wrong language, 15) understanding EOP through Google Classroom, 16) liking EOP through Google Classroom, 17) being motivated in EOP through Google Classroom, 18) perceiving positively EOP through Google Classroom, 19) perceiving EOP flexibility through Google Classroom, and 20) perceiving EOP positively with learning materials, examples or illustrations.

\section{RESEARCH METHOD}

The present research was designed using a Mixed Method (Cresswelland Clark, 2011). The objective was to measure and identify EFL teachers' ability in preparing, implementing, and constraints found in these activities as well as the students' constraints in learning EOP through Google Classroom in the Senior Vocational High School Denpasar(Alwright et.al,1991; Hopkins,2008). The teachers' ability in preparing and implementing lesson plans for EOP through Google Classroom were measured and described quantitatively. Whilst, the teachers' and students' constraints were qualitatively described and analyzed. The teachers' ability in preparing and implementing lesson plans for EOP through Google Classroom were rated in terms of $1=$ very poor; $2=$ poor; $3=$ good; $4=$ very good. The raw scores were then transformed into T-score with the mean $=50.00$ and the standard deviation $=10.00$. (Hinkle et al,1979).

Teachers' constraints in preparing lesson plans for EOP through Google Classroom were gathered in two steps. First, they had to rate their ability on each aspect of lesson plan's preparation and implementation as objectively as they experienced. Second, they had to conform the rating with the constraint aspects using a rubric. Teachers' constraints in preparing lesson plans consisted of eight items, they are, relevance of learning indicators with basic competency, 2) relevance of learning materials, learning indicators with basic competency, 3) relating learning methods, 4) relevance of learning procedures or steps, 5) relevance of evaluation and learning indicators, 6) relevance of evaluation instruments and techniques, 7) relevance of Information Technology, and 8) using Information Technology. Whilst, teachers' constraints in implementing lesson plans through Google Classroom 
deviation or $67.92 \pm 1.73$ ). The variability of scores among EFL in Boga, Busana, and Perhotelan is not very large (variance statistic $=2.99$ ). The range statistic $=5.00$ between the minimum and maximum scores.

When analyzed per aspect, teacher's ability in Boga was less able in relating learning materials, learning indicators with basic competency, as well as relating learning methods or techniques with learning materials for basic competencies 2 and 3 . Teacher's ability in Busana is found less able in relating learning methods or techniques with learning materials learning materials for basic competency 1 , as well as less able to relate learning materials, learning indicators with basic competency, as well as relating learning methods or techniques with learning materials for basic competencies in basic competency 4. Finally, teacher's ability in Perhotelanis found less able in relating learning methods or techniques with learning materials learning materials for basic competency 1 , as well as less able to relate learning materials, learning indicators with basic competency, as well as relating learning methods or techniques with learning materials for basic competencies for basic competencies 1,2 and 4.In conclusion, the EFL teachers in Boga, Busana, and Perhotelan were less able in stating learning indicators using operational and measurable words as well as finding learning indicators relevant to the basic competency, preparing learning materials incorporating principles of authenticity, context, variation, relevant and consistent to the basic competency and learning indicators, selecting learning methods or techniques based on teachers' ability, learning materials, students' characteristics, and basic competency as well as learning indicators, and conducting learning evaluation containing aspects of reliability, validity, objectivity, and consistent with efficiency.

\section{Implementing Lesson Plan}

Implementing lesson plans for EOP through Google Classroom were measured by nine aspects. Data on the teachers' ability in implementing lesson plans for EOP through Google Classroom in the Senior Vocational High School Denpasar are shown in the following tables.

Table 2. Selected Descriptive Statistics of Teachers' Ability in Implementing Lesson Plans

\begin{tabular}{ccccccc}
\hline Range & Minimum & Maximum & \multicolumn{2}{c}{ Mean } & Std. & Variance \\
\cline { 5 - 6 } & Statistic & Statistic & Statistic & Statistic & $\begin{array}{c}\text { Std. } \\
\text { Deviation } \\
\text { Error }\end{array}$ & Statistic \\
\hline 2.00 & 64.75 & 66.75 & 65.50 & 0.50 & 1.73 & 2.99 \\
\hline
\end{tabular}

Source: Data analysis of December 2020 SPSS Version 25.

Table 2 shows that the teachers' ability mean score in implementing lesson plans for EOP through Google Classroom $=65.50$. When the teachers' ability mean scores ordered, mean score $=66.75$ is the highest in Perhotelan, followed by teacher's ability mean score = 65.00 in Boga and 64.75 in Busana. However, when the teachers' ability mean scores were categorized, they are all in the moderate category (mean \pm 1 standard deviation or $65.50 \pm$ 1.73). The variability of scores among EFL in Boga, Busana, and Perhotelan is not very large (variance statistic $=2.99$ ) . The range statistic $=2.00$ between the minimum and maximum scores.

When analyzed per aspect, teacher's abilities that were less able in implementing lesson plans for EOP through Google Classroom in Boga consist of mastering learning materials, selecting appropriate learning media, utilizing learning media, and using oral as well as written English in basic competency 1 and 2 ; the teacher was less able in selecting appropriate learning media in basic competency 3 and 4. In Busana, the teacher was less able in mastering learning materials, selecting appropriate learning media, utilizing the already selected learning media, and using oral as well as written English in competency 1; also less able in mastering learning materials, selecting appropriate learning media, and using oral as well as written English in basic competency 2; less able in selecting appropriate learning media and using oral as well as written English in basic competency 3; less able in implementing scientific approach, utilizing the already selected learning media, and using oral as well as written English in competency 3. Finally, the teacher was less able in implementing scientific approach, utilizing the already selected learning media, and using 
oral as well as written English in basic competency 4. In Perhotelan, EFL teacher was less able in selecting appropriate learning media, utilizing the already selected learning media, and using oral as well as written English in basic competency 1; the teacher was less able in utilizing the already selected learning media in basic competency 2 ; the teacher was also less able in utilizing the already selected learning media and using oral as well as written English in basic competency 3; finally, the teacher was less able in utilizing the already selected learning media in EOP in basic competency 4. In conclusion, the teacher in Boga, Busana, and Perhotelan was less able in mastering learning materials, implementing scientific approach, selecting appropriate learning media for EOP, utilizing the already selected learning media in EOP, and using oral as well as written English in EOP.

\section{Teachers' Constraints in Preparing Lesson Plans}

In preparing lesson plans for EOP through Google Classroom, EFL teachers found difficulties or constraints. Teachers were asked to rate their ability in preparing lesson plans as objectively as possible as they experienced. After self-rating, they described sources or descriptions of constraint in each aspect of lesson plans.

The teacher in Boga found difficulty in aspect 1 especially in stating learning indicators using operational and measurable words as well as finding learning indicators relevant to the basic competency; in aspect 2 especially in preparing learning materials incorporating principles of authenticity, context, variation, relevant and consistent to the basic competency and learning indicators; in aspect 3 especially in selecting learning methods or techniques based on teachers' ability, learning materials, students' characteristics, and basic competency as well as learning indicators; in aspect 5 especially in conducting learning evaluation containing aspects of reliability, validity, objectivity, and consistent with efficiency.

\section{Teachers' Constraints in Implementing Lesson Plans}

In implementing lesson plans for EOP through Google Classroom, EFL teachers found difficulties or constraints. Teachers were asked to rate their ability in implementing lesson plans as objectively as possible as they experienced. After self-rating, they described sources or descriptions of constraint in each aspect of implementing lesson plans.

Teachers in Boga, Busana, and Perhotelan in the Senior Vocational School Denpasar also found difficulty in implementing the lesson plans for EOP through Google Classroom., especially in relating old and new learning materials in opening class, learning materials with sufficient learning materials for respective competency, learning materials with authentic, contextual, and varied learning materials, learning with association and communication.

\section{Students' Constraints Using On-Line Learning}

Students also found difficulty in learning EOP through Google Classroom in the Senior Vocational High School Denpasar. Their constraints were probed in twenty items. In general, the items asked them to disclose some facilitative and technical problems or difficulties in learning EOP through Google Classroom. The obtained data are shown in the following table.

Table 3.Students' Constraints in Learning EOP through Google Classroom Items Responses:

A

B

C

$\mathrm{D}$

\begin{tabular}{ccccccccc} 
& $\mathrm{f}$ & $\%$ & $\mathrm{f}$ & $\%$ & $\mathrm{f}$ & $\%$ & $\mathrm{f}$ & $\%$ \\
\hline 1 & 83 & 100 & 0 & 0 & 0 & 0 & 0 & 0 \\
2 & 83 & 100 & 0 & 0 & 0 & 0 & 0 & 0 \\
3 & 83 & 100 & 0 & 0 & 0 & 0 & 0 & 0 \\
4 & 83 & 100 & 0 & 0 & 0 & 0 & 0 & 0 \\
5 & 83 & 100 & 0 & 0 & 0 & 0 & 0 & 0 \\
6 & 83 & 100 & 0 & 0 & 0 & 0 & 0 & 0 \\
7 & 83 & 100 & 0 & 0 & 0 & 0 & 0 & 0 \\
8 & 83 & 100 & 0 & 0 & 0 & 0 & 0 & 0 \\
9 & 0 & 0 & 83 & 0 & 0 & 0 & 0 & 0 \\
\hline
\end{tabular}




\begin{tabular}{ccccccccc}
\hline 10 & 83 & 100 & 0 & 0 & 0 & 0 & 0 & 0 \\
11 & 83 & 100 & 0 & 0 & 0 & 0 & 0 & 0 \\
12 & 0 & 0 & 83 & 0 & 0 & 0 & 0 & 0 \\
13 & 0 & 0 & 83 & 0 & 0 & 0 & 0 & 0 \\
14 & 83 & 100 & 0 & 0 & 0 & 0 & 0 & 0 \\
15 & 0 & 0 & 83 & 100 & 0 & 0 & 0 & 0 \\
16 & 53 & 63.86 & 30 & 36.14 & 0 & 0 & 0 & 0 \\
17 & 53 & 63.86 & 30 & 36.14 & 0 & 0 & 0 & 0 \\
18 & 53 & 63.86 & 30 & 36.14 & 0 & 0 & 0 & 0 \\
19 & 53 & 63.86 & 30 & 36.14 & 0 & 0 & 0 & 0 \\
20 & 53 & 63.86 & 30 & 36.14 & 0 & 0 & 0 & 0 \\
\hline
\end{tabular}

Table 3 shows that students found difficulties or constraints in 1) understanding EOP through Google Classroom learning platform (36.14\%), 2) disliking EOP through Google Classroom learning platform $(36.14 \%, 3)$ being demotivated in learning EOP through Google Classroom learning platform $(36.14 \%)$, 4) being negatively perceived in learning EOP through Google Classroom platform, and 5) perceiving positively to provide them with rich with learning materials, plenty of examples, or varied illustrations. In conclusion, the EFL students found 5 aspects of EOP through Google Classroom learning paradigm.

The research findings show that EFL teachers were less able to prepare and implement lesson plans for EOP through Google Classroom in the Senior Vocational High School Denpasar. More specifically, they were less able in 1) stating the learning indicators using operational and measurable words, 2) identifying learning indicators which are relevant to basic competency.

The less ability of EFL teachers in the Senior Vocational School Denpasar in preparing and implementing lesson plans for EOP through Google Classroom are related to 1) adaptability struggle,2) technical issues, 3) computer literacy, 4) time management, and 5) self-motivation. Moreover, EFL teachers and students are not computer literate. Most of them are not able to manage computers well, or even could not operate basic programs such as Microsoft Word and Power Point let alone Google Classroom Time management is a difficult task for EFL teachers and students as on-line learning require a lot of time and intensive work. Self-motivation on e-learning is an essential requirement; however, many EFL teachers and students lack it.

In the present research, the meaning of implication is that the action should be taken by EFL teachers and students in the Senior Vocational High School in Denpasar Teachers' inability in preparing and implementing lesson for EOP through Google Classroom urge EFL teachers and students: 1).To improve themselves in participating on some workshop about online learning through Google Classroom, 2) to accustom themselves to switch from traditional classroom to online learning, 3) to provide themselves with high bandwidth or strong internet connection that on-line courses require, and thus succeed to catch up with virtual leanings or limit the technical issues (Bates and Poole, 2003; Akyoland Garrison,2011); 4)to improve their computer literacy in order to be able to manage computers well, 5) to improve time management on-line learning which requires a lot of time and intensive work. Self-motivation on e-learning is an essential requirement.

\section{CONCLUSION AND SUGGESTIONS}

EFL teachers were less able in stating learning indicators using operational and measurable words as well as finding learning indicators relevant to the basic competency.EFL teachers were less able implementing lesson plans and found some constraints, especially in relating old and new learning materials in opening class, learning materials with sufficient learning materials for respective competency, learning materials with authentic, contextual, and varied learning materials, learning with association and communication EFL students were also constrained in learning EOP through Google Classroom, especially in understanding EOP through Google Classroom learning platform.

EFL teachers are suggested to understand of taxonomy bloom and participate some workshops to improve in developing teaching objectives.EFL students and teachers are suggested to be accustomed to switch from traditional classroom and face to face instructor 
training to computer-based learning in a virtual classroom which make the learning experience entirely different.

\section{REFERENCES}

Adnan, M. (2020). Online learning amid the COVID-19 pandemic: Students perspectives. Journal of Pedagogical Research, 1(2), 45-51. https://doi.org/10.33902/jpsp.2020261309

Akyol,Z.\&Garrison,D.R.(2011). Understanding cognitive presence in an online and blended community of inquiry:Assessing outcomes and processes for deep approaches to learning. British Journal of Educational Technology,42(2),233-250.

Cresswell, J.W. \& Clark, V.L. (2011). Designing and conducting mixed methods research. Thousand Oaks, CA: Sage.

Harjanto, A. S., \& Sumarni, S. (2019). Teacher's Experiences on The Use of Google Classroom. 3rd English Language and Literature International Conference (ELLiC), 3, 172-178.

Indonesia, P. R. (2012). PPRI No. 81 Tahun 2012. Undang-Undang, Unknown(Unknown), No Pages.

Hinkle,D.E.,Wiersma,W., \&Jurs,S.G. (1979). Applied Statistics for Behavioral Sciences. Boston: Houghton Mifflin Company.

Indonesia, M. P. dan K. R. (2020). Pencegahan Corona Virus Disease (Covid-L9) Pada Satuan Pendidikan. Surat Edaran Nomor 3, 1-5.

Kumar, J. A., \& Bervell, B. (2019). Google Classroom for mobile learning in higher education: Modelling the initial perceptions of students. Education and Information Technologies, 24(2), 1793-1817. https://doi.org/10.1007/s10639-018-09858-z

Mork, C.-M. (2014). Benefits of using online student response systems in Japanese EFL classrooms. The JALT CALL Journal, 10(2), 127-137. https://doi.org/10.29140/jaltcall.v10n2.171

Namaziandost, E. (2019). 1031-3323-1-PB.pdf. 6(3), 199-215.

Prasetyaningtyas, S. (2020). Pelaksanaan Belajar Dari Rumah ( BDR ) Secara Online Selama Darurat Covid-19 Di SMP N 1 Semin. Ideguru: Jurnal Karya Ilmiah Guru, 5(1), 86-94. Retrievedfromhttps://jurnaldikpora.jogjaprov.go.id/index.php/jurnalideguru/article/view/139/165

Rahmad, R., Adria Wirda, M., Berutu, N., Lumbantoruan, W., \& Sintong, M. (2019). Google classroom implementation in Indonesian higher education. Journal of Physics: Conference Series, 1175(1). https://doi.org/10.1088/1742-6596/1175/1/012153

Ramadhani, R., Umam, R., Abdurrahman, A., \& Syazali, M. (2019). The effect of flippedproblem based learning model integrated with LMS-google classroom for senior high school students. Journal for the Education of Gifted Young Scientists, 7(2), 137-158. https://doi.org/10.17478/jegys.548350

Ratnaningsih, P. W. (2019). the Use of Google Classroom Application for Writing and Speaking in English Education Class. Paskalina Widiastuti Ratnaningsih Indonesian EFL Journal: Journal of ELT, Linguistics, and Literature, 5(1), 2019. Retrieved from http://ejournal.kopertais4.or.id/mataraman/index.php/efi 